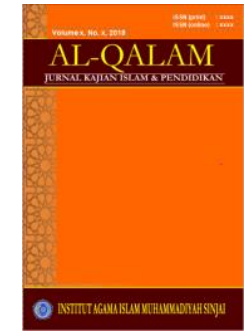

AL-QALAM

Jurnal Kajian Islam \& Pendidikan

Volume 7, No. 1, 2015

ISSN (print) : 1858-4152

ISSN (online) : 2715-5684

Homepage : http://journal.al-qalam.iaims.ac.id

\title{
KREATIVITAS GURU AGAMA ISLAM DALAM MENUMBUHKAN MOTIVASI BELAJAR
}

\author{
Oleh : Jamaluddin* \\ $* * *$
}

\begin{abstract}
Abstrak
Prestasi belajar merupakan hal yang tidak dapat dipisahkan dari kegiatan belajar karena kegiatan belajar merupakan proses, sedangkan prestasi merupakan hasil dari proses belajar. Motivasi dapat berfungsi sebagai pendorong usaha dan pencapaian prestasi. Seseorang melakukan suatu usaha karena adanya motivasi yang baik akan menunjukkan hasil yang baik pula. Dengan demikian dituntut peran orang tua dan guru untuk selalu memotivasi peserta didik diberbagai rana kehidupan maupun lingkungan belajarnya. Salah satu inisiatif guru agama yang dapat menumbuhkan kreativitas belajar siswa pada tujuan utama pendidikan yaitu dengan menggunakan metode probing question (pertanyaan menggali) dengan menggunakan metode probing question menjadikan siswa lebih kreatif dalam berfikir dan siswa mendapatkan informasi dari jawaban yang lengkap dan jelas.
\end{abstract}

Kata Kunci : Kreativitas, Guru, Motivasi, Belajar

\section{PENDAHULUAN}

Pendidikan nasional yang berdasarkan Pancasila dan Undang-Undang Dasar Negara Republik Indonesia tahun 1945 berfungsi mengembangkan kemampuan dan membentuk watak serta peradaban bangsa yang bermartabat dalam rangka mencerdaskan kehidupan bangsa, bertujuan untuk mengembangkan potensi peserta didik agar menjadi manusia yang beriman dan bertaqwa kepada Tuhan Yang Maha Esa, berakhlaq mulia, sehat, berilmu, cakap, kreatif, mandiri, dan menjadi warga Negara yang demokratis serta bertanggung jawab. ${ }^{1}$

Berdasarkan fungsi pendidikan nasional di atas, peran guru menjadi kunci keberhasilan dalam mengembangkan misi pendidikan dan pembelajaran disekolah selain bertanggung jawab untuk mengatur, mengarahkan dan menciptakan suasana kondusif yang mendorong siswa untuk melaksanakan kegiatan dikelas. Mengingat sangat kompleksnya tujuan pendidikan, maka betapa besar dan berat tugas seorang pendidik dalam menciptakan kualitas hasil pendidikan. Ketrampilan guru mengajar sangat besar pengaruhnya terhadap hasil pendidikan (out put). ${ }^{2}$ Keterampilan guru dalam mengajar merupakan faktor yang paling dominan dalam upaya mentrasfer ilmu pengetahuan pada paserta didik, karena hal itu dapat

\footnotetext{
${ }^{*}$ Dosen Tetap STAI Muhammadiyah Sinjai

${ }^{1}$ M. Dawam Rahardja, Islam Indonesia Menatap Masa Depan. (Jakarta:P3M, 1989), h. 10

${ }^{2}$ Ibid, h.10-11
} 


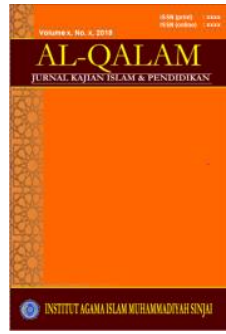

AL-QALAM

Jurnal Kajian Islam \& Pendidlikan

Volume 7, No. 1, 2015

ISSN (print) : 1858-4152

ISSN (online) : 2715-5684

Homepage : http://journal.al-qalam.iaims.ac.id

mengatasi kebosanan siswa dalam belajar, sehingga tercipta suasana belajar yang kreatif dan menyenangkan.

Mengajar adalah tindakan kompleks yang memerlukan inisiatif mengajar agar siswa mempunyai kreativitas yang tinggi terhadap pelajaran yang disajikan. Jika guru tidak banyak berinisiatif dalam mengajar maka kegiatan pembelajaran akan membosankan siswa, perhatian siswa kurang, mengantuk dan akibatnya tujuan pembelajaran tidak tercapai sesuai dengan harapan. $^{3}$

Inisiatif dapat timbul dari mana saja, yang tercipta karena adanya dorongan atau keinginan dalam diri seseorang untuk melakukan sesuatu. Secara umum guru dikatakan inisiator apabila memiliki ciri antara lain: ${ }^{4} 1$ ) Mengembangkan atau menyempurnakan hal yang sudah ada sehingga menjadi lebih sempurna; 2) Menemukan hal baru yang belum ada dalam dunia pendidikan; 3)Mengacu pada tujuan pendidikan nasional, institusional, dan kulikuler; 4) Mempunyai gagasan baru untuk diterapkan dalam kelas; 5) Mampu memadukan antara teori dan praktik; 6) Mampu menjabarkan buku teks ajar dengan lingkungan sekitar; 7) Memotivasi anak mempelajari lingkungan alam untuk disesuaikan dengan buku teks aja; 8) Memberi contoh pada peserta didiknya untuk disiplin dan bertanggung jawab; 9) Memotivasi anak didik untuk mengadakan pengamatan fenomena sosial dan penelitian ilmiah pada alam; 10) Memotivasi peserta didik untuk mengkritisi buku teks ajar dan mengembangkannya sesuai dengan situasi dan kondisi masyarakat global.

Di dalam UU No. 20 Tahun 2003 tentang Sistem Pendidikan Nasional pasal 3, di ungkapkan bahwa pendidikan nasional berfungsi mengembangkan kemampuan dan membentuk watak serta peradaban bangsa yang bermartabat dalam rangka mencerdaskan kehidupan bangsa, bertujuan untuk berkembangnya potensi peserta didik agar menjadi manusia yang beriman dan bertakwa kepada Tuhan Yang Maha Esa, berakhlak mulia, sehat, berilmu, cakap, kreatif, mandiri, dan menjadi warga negara yang demokratis serta bertanggung jawab. Untuk mencapai tujuan tersebut, salah satu bidang studi yang harus dipelajari oleh peserta didik baik di madrasah maupun sekolah adalah Pendidikan Agama Islam, yang dimaksudkan untuk membentuk peserta didik menjadi manusia yang beriman dan bertakwa kepada Tuhan Yang Maha Esa serta berakhlak mulia. ${ }^{5}$

Dengan demikian pelaksanaan pendidikan agama termasuk Pendidikan Agama Islam (PAI) di sekolah diatur oleh Undang-Undang, baik yang berkaitan dengan sarana dan prasana pendidikan, biaya pendidikan, tenaga pengajar, kurikulum, dan komponen pendidikan lainnya. ${ }^{6}$ Bahkan pendidikan agama menempati tempat yang strategis secara operasional yaitu pendidikan agama menjadi landasan dalam pendidikan nasional demi mewujudkan manusia Indonesia seutuhnya sesuai amanat pancasila dan UUD 1945.

Tantangan eksternal Pendidikan Agama Islam pada era kemajuan IPTEKS saat ini, dimana perubahan global semakin cepat terjadi dengan adanya kemajuan-kemajuan dari

\footnotetext{
${ }^{3}$ Muhadjir, Noeng. Mencari Paradigma Untuk Membuat Antisipasi. Makalah Disampaikan Pada Kulaih Pascasarjana IAIN Yogyakarta (Yogyakarta: IAIN Yogyakarta), h.

${ }^{4}$ Ibid, h. 8-9

${ }^{5}$ Undang-Undang RI No. 20 Tahun 2003 Tentang Sistem Pendidikan Nasional.

6 Abdul Rachman Shaleh, Pendidikan Agama dan Pembangunan watak Bangsa (Jakarta: Grafindo Persada, 2005), h. 17.
} 


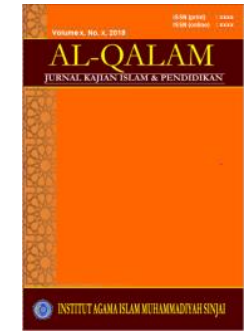

AL-QALAM

Jurnal Kajian Islam \& Pendidikan

Volume 7, No. 1, 2015

ISSN (print) : 1858-4152

ISSN (online) : 2715-5684

Homepage : http://journal.al-qalam.iaims.ac.id

negara maju di bidang teknologi informasi dan komunikasi. Kemajuan IPTEKS ini mendorong semakin lajunya proses globalisasi. Harus diakui perkembangan IPTEKS di satu sisi telah secara nyata mempengaruhi bahkan memperbaiki taraf dan mutu hidup manusia. Di sisi lain, kemajuan IPTEKS telah mempengaruhi bangunan kebudayaan dan gaya hidup manusia. $^{7}$

\section{PEMBAHASAN}

\section{A. Kreativitas Guru Pendidikan Agama Islam}

\section{Pengertian Kreativitas}

George D. Stoddard dalam bukunya creativity in education sebagaimana dikutip Julius Candra, menyatakan menjadi kretif berarti menjadi tidak dapat diterka atau diramalkan sebelumnya (unpredic table). Kreativitas adalah dinamika yang membawa perubahan yang berarti, entah dalam dunia kebudayaan, dunia ide, dunia seni atau struktur social. ${ }^{8}$ Definisi tentang kreativitas ini mencakup kenyataan energi dan spontanitas manusia. Manusia dapat berubah-ubah dalam putaran waktu. Selama itu juga mereka melakukan hal-hal yang luar biasa yang tidak pernah dipikirkan sebelumnya yang mungkin merupakan bentuk kreativitas yang belum pernah terjadi sebelumnya.

Sedangkan Rogers menekankan bahwa sumber dari kreativitas adalah kecenderungan untuk mengaktualisasi diri, mewujudkan potensi, dorongan untuk berkembang dan menjadi matang, kecenderungan untuk mengekspresikan dan mengaktifkan semua kemampuan organisme. ${ }^{9}$ Kreativitas dapat dinilai ketika hal tersebut tertuang dalam suatu tindakan nyata. Ketika pemikiran baru belum dituangkan, maka itu adalah proses menuju kreatif.

Apapun definisi kreativitas, tetaplah ia berpusat pada otak manusia. Kreativitas terjadi karena keseluruhan bagian otak bekerja secara bersamaan, terpadu pada suatu waktu tertentu, dengan tetap melakukan spesialisasi masing-masing. Otak dengan sigap menaggapi setiap informasi yang masuk. Kadar pengelolaan otak akan sangat menentukan tingkat kreativitas seseorang. Karena itu otak harus dilatih, tidak hanya dengan makanan bergizi tetapi dengan latihan berfikir yang terus menerus. ${ }^{10}$

Untuk dapat melahirkan kreativitas, seseorang harus dapat memanfaatkan kedua sifat otak kiri dan kanan. Otak kiri yang bersifat logika, berurutan, lisan, pertambahan dan dominan. Sedangkan otak kanan bersifat emosi, lompatan, visual, menyeluruh dan tersembunyi. Akhir-akhir ini, istilah otak kanan telah digunakan sebagai cara popular untuk menyatakan kreatif, artistik dan rapi. Kreativitas muncul dari interaksi luar biasa antara kedua otak.

Kreativitas menurut Clark Moustakes adalah pengalaman mengespresikan dan mengaktualisasikan identitas individu dalam bentuk terpadu dalam hubungan dengan diri

\footnotetext{
${ }^{7}$ Muhaimin, et. al., Paradigma Pendidikan Islam: Upaya Mengektifkan Pendidikan Agama Islam Di Sekolah, (Bandung: PT Remaja Rosdakarya, 2004), h.85

8 Julius Candra, Kreativitas: Bagaimana Menanam, Membangun dan Mengembangkannya, (Yogyakarta: Kanisius, 1994), h. 13

${ }^{9}$ Utami Munandar, Pengembangan Kreativitas Anak Bakat, (Jakarta: PT. Rineka Cipta, 1999), h. 18

10 Taufik Pasiak, Revolusi IQ/EQ/SQ, (Bandung: Mizan, 2003), h. 11
} 


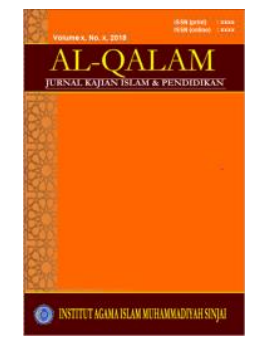

AL-QALAM

Jurnal Kajian Islam \& Pendidikan

Volume 7, No. 1, 2015

ISSN (print) : 1858-4152

ISSN (online) : 2715-5684

Homepage : http://journal.al-qalam.iaims.ac.id

sendiri, dengan alam dan orang lain Oleh karena itu, masa pertumbuhan siswa harus dipelihara, diisi dengan hal-hal yang sesuai dengan sifat fitrahnya yang terletak diberikan Allah perlu ditanamkan rasa ketaqwaan, keimanan, kepribadian yang baik, kreativitas, intelegensi serta situasi yang indah, kelak akan menjadi manusia yang berkepribadian baik serta berguna bagi nusa dan bangsa. ${ }^{11}$

Dari pengertian-pengertian tersebut dapat diambil standar kreativitas adalah baru, unik, berbeda dan bermanfaat serta lebih baik. Orang yang kreatif membawa makna dan tujuan baru, menyelesaikan masalah dan memberikan nilai tambah atau keindahan. Sedangkan belajar diartikan sebagai suatu proses usaha yang dilakukan individu untuk memperoleh tingkah laku baru secara keseluruhan sebagai hasil pengalaman individu itu sendiri dalam interaksi dengan lingkungan. ${ }^{12}$

Belajar mengandung pengertian terjadinya perubahan dari persepsi dan perilaku, termasuk juga perubahan perilaku. lingkungan belajar merupakan factor penting dalam pendidikan yaitu guru dan orang tua yang dapat membantu dalam proses belajar, yang akan dapat membentuk lingkungan pembelajaran. ${ }^{13}$

\section{Guru Pendidikan Agama Islam}

Guru agama atau pendidik ialah orang yang memikul tanggung jawab untuk membimbing. Guru tidak sama dengan pengajar, sebab pengajar itu hanya sekedar menyampaikan materi pelajaran kepada murid. Prestasi yang tertinggi yang dapat dicapai oleh seorang pengajar apabila ia berhasil membuat pelajar memahami dan menguasai materi pelajaran yang diajarkan kepadanya. Tetapi seorang pendidik bukan hanya bertanggungjawab menyampaikan materi pengajaran kepada murid saja tetapi juga membentuk kepribadian seorang anak didik bernilai tinggi. ${ }^{14}$

K.H. Moh. Syafi'i Hadzami mengatakan guru agama adalah "pemimpin dan pembimbing rohani umat". ${ }^{15}$ Salah satu inisiatif guru agama yang dapat menumbuhkan kreativitas belajar siswa pada tujuan utama pendidikan yaitu dengan menggunakan metode probing question (pertanyaan menggali) dengan menggunakan metode probing question menjadikan siswa lebih kreatif dalam berfikir dan siswa mendapatkan informasi dari jawaban yang lengkap dan jelas.

\section{Fungsi dan Peran Guru Pendidikan Agama Islam}

Fungsi dan peran guru agama dalam interaksi edukatif sama dengan guru pada umumnya. Guru mempunyai fungsi dan peran yang penting dalam interaksi edukatif di sekolah. Karena tugasnya yang mulia, seorang guru menempati posisi yang mulia yang berfungsi

1). Guru sebagai pemberi pengetahuan yang benar kepada muridnya.

\footnotetext{
${ }^{11}$ Muhadjir, Noeng. Op.cit. h. 10

12 Abu Ahmadi. Psikologi Belajar, (Jakarta: Rineka Cipta, 1991), h. 22

${ }^{13}$ Oemar Hamalik, Psikologi Belajar Mengajar, (Bandung: PT. Sinar Baru al Gesindo, 2000), h.47

${ }^{14}$ R.A. Mayulis, Ilmu Pendidikan Islam, (Jakarta : Kalam Mulia, 1998), h.36

${ }^{15}$ Moh. Syafi'I Hadcami, Tauhidul Addilah. (Surabaya: Menara Kusud, 1986) H, 116.
} 


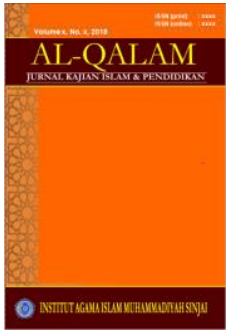

AL-QALAM

Jurnal Kajian Islam \& Pendidilkan

Volume 7, No. 1, 2015

ISSN (print) : 1858-4152

ISSN (online) : 2715-5684

Homepage : http://journal.al-qalam.iaims.ac.id

2). Guru sebagai pembina akhlak yang mulia.

3). Guru sebagai pemberi petunjuk kepada anak tentang hidup yang baik. ${ }^{16}$

Peran dan kedudukan guru yang tepat dalam interaksi edukatif akan menjamin tercapainya tujuan pendidikan yang diharapkan. Dalam interaksi edukatif, anak-anak juga menemui berbagai kesulitan. Setiap anak tumbuh dan berkembang dalam berbagai irama dan variasi sesuai dengan kodrat yang ada padanya. Ia akan belajar sekalipun akan berhasil atau tidak dan juga dia tidak memikirkan apakah tingkah lakunya mendatangkan pujian atau tidak. Ia belajar dengan caranya sendiri-sendiri, sesuai dengan kemampuan dan potensi serta keterampilan dan bakat yang ada padanya, ia belajar sesuai dengan individunya masingmasing peran guru dalam membantu proses belajar murid sangatlah diharapkan. Setiap guru harus mengetahui serta berusaha untuk memecahkan kesulitannya. ${ }^{17}$

Menurut Zakiah Daradjat, unsur-unsur pokok yang perlu dipertahankan dalam masalah belajar adalah sebagai berikut :

1) Kegairahan dan kesediaan untuk belajar,

2) Membangkitkan Minat Murid,

3) Menumbuhkan sikap dan bakat yang baik,

4) Mengatur proses belajar mengajar,

5) Berpindahnya pengaruh belajar dan pelaksanaannya dalam kehidupan nyata.

6) Hubungan manusiawi dalam prose belajar mengajar ${ }^{18}$

Roestiyah NK menyatakan peranan guru dalam interaksi edukatif adalah sebagai berikut :

1) Fasilitas, yakni menyediakan situasi dan kondisi yang dibutuhkan individu yang belajar.

2) Pembimbing, yakni memberikan bimbingan terhadap siswa dalam interaksi belajar mengajar, agar siswa tersebut mampu belajar dengan lancar dan berhasil secara efektif dan efisien.

3) Motivator, yakni memberikan dorongan dan semangat agar siswa mau giat belajar.

4) Organisator, yakni mengorganisasikan kegiatan belajar siswa maupun guru.

5) Manusia sumber, dimana guru dapat memberikan informasi yang dibutuhkan oleh siswa, baik berupa pengetahuan, keterampilan maupun sikap. ${ }^{19}$

\section{B. Motivasi Belajar Siswa}

\section{Pengertian Motivasi}

Kata motivasi berasal dari bahasa inggris "Motivation" dan merupakan bentukan dari kata "Motive” yang berarti alasan atau yang menggerakkan. ${ }^{20}$ Adapun secara terminologi

\footnotetext{
${ }^{16}$ Abdul Khaliq, Diklat Tentang Pendidik. Loc. Cit., h, 8

${ }^{17}$ Ramayulis, Ilmu Pendidikan Islam. (Jakarta: Kalam Mulia, 1994), h. 45

${ }^{18}$ Zakiah Daradjat, Kepribadian Guru. (Jakarta : Bulan Bintang, 1980), h 15

${ }^{19}$ Roestiyah NK. Masalah Pengajaran Sebagai Suatu Sistem. (Jakarta : PT. Bina Aksara, 1982), h.46

20 John M. Echols dan Hasan Shadily, Kamus Inggris Indonesia, (Cet. XXIV, Jakarta : PT. Gramedia
} Pustaka Utama, 2000), h. 386. 


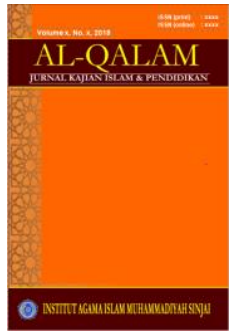

AL-QALAM

Jurnal Kajian Islam \& Pendidikan

Volume 7, No. 1, 2015

ISSN (print) : 1858-4152

ISSN (online) : 2715-5684

Homepage : http://journal.al-qalam.iaims.ac.id

motivasi merupakan suatu tenaga, dorongan, alasan kemauan dari dalam yang menyebabkan kita bertindak, dimana tindakan itu di arahkan kepada tujuan tertentu yang hendak dicapai. ${ }^{21}$

Ngalim Purwanto mendefinisikan motivasi adalah, " pendorong” suatu usaha yang di sadari untuk mempengaruhi tingkah laku seseorang agar ia tergerak hatinya untuk bertindak melakukan sesuatu sehingga mencapai hasil atau tujuan tertentu. ${ }^{22}$

Dewasa ini, definisi motivasi sebanyak jumlah psikolog. Yang paling sederhana menyatakan, motivasi mencakup apa saja yang bias melahirkan, memelihara dan mengarahkan perilaku. Meskipun para ahli mendefinisikan motivasi dengan cara dan gaya yang berbeda, namun esensinya menuju kepada maksud yang sama, ialah bahwa motivasi itu merupakan Suatu kekuatan (Power) atau tenaga (forces) atau daya (energy); atau Suatu keadaan yang kompleks (a Complex State) dan kesiap sediaan (Preparatory State) dalam diri Individu (Organisme) untuk bergerak (to Move, motion motives) kearah tujuan tertentu baik disadari maupun tidak tidak disadari.$^{23}$

\section{Aspek-aspek Motivasi}

Setiap gerak dan tindakan manusia akan selalu berbarengan dengan motivasi. Menurut Abraham Maslow yang dikutip oleh Chalijah Hasan, bahwa klasifikasi motivasi dalam diri manusia dapat dibagi dalam beberapa kelompok, yaitu:

a. Fisiologis Hal ini merupakan kebutuhan manusia yang paling dasar, meliputi kebutuhan makanan, pakaian, tempat berlindung, yang penting untuk mempertahankan hidup.

b. Rasa aman Hal ini merupakan kebutuhan kepastian keadaan dan lingkungan yang dapat diramalkan, ketidak pastian, ketidakadilan, keterancaman akan menimbulkan kecemasan dan ketakutan pada diri individu.

c. Rasa cinta Hal ini merupakan kebutuhan afeksi dan pertalian dengan orang lain.

d. Penghargaan Yaitu kebutuhan rasa berguna, penting dihargai, dikagumi, dihormati oleh orang lain, secara tidak langsung ini merupakan kebutuhan perhatian, ketenaran, status, martabat dan lain-lainnya.

e. Aktualisasi diri Yaitu kebutuhan mengembangkan diri sepenuhnya, merealisasikan potensi-potensi yang di milikinya.

f. Pengetahuan dan mengerti Hal ini merupakan kebutuhan manusia untuk memuaskan rasa ingin tahunnya, untuk mendapatkan pengetahuan, untuk mendapatkan keteranganketerangan dan untuk mengerti sesuatu.

g. Kebutuhan estetis Hal ini adalah kebutuhan perlunya perasaan ini dinilai dari indah dan jelek, sehingga manusia menginginkan hal yang termasuk indah dalam hidupnya. ${ }^{24}$

\section{Fungsi Motivasi}

\footnotetext{
${ }^{21}$ Sumadi Suryabrata, Psikologi Pendidikan, ( Jakarta : Rajawali Pers, 1990), h. 72.

${ }_{22}^{2}$ M. Ngalim Purwanto, Psikologi Pendidikan., (Bandung :PT. Remaja Rosda Karya, 1996), h. 71.

23 Abin Syamsuddin Makmun, Psikologi Pendidikan, (Cet V, Bandung: PT. Remaja Rosda Karya, 2002), h.37.

${ }^{24}$ H. Chalijah Hasan, Dimensi-dimensi Psikologi Pendidikan, (Surabaya :Al-Ikhlas, 1994), h. 145-147.
} 


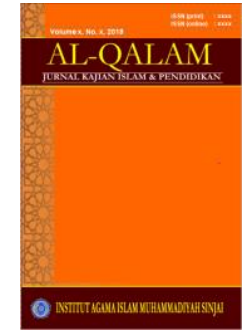

AL-QALAM

Jurnal Kajian Islam \& Pendidikan

Volume 7, No. 1, 2015

ISSN (print) : 1858-4152

ISSN (online) : 2715-5684

Homepage : http://journal.al-qalam.iaims.ac.id

Motivasi berhubungan dengan suatu tujuan. motivasi itu mempengaruhi adanya kegiatan. Sehubungan dengan itu maka ada tiga fungsi motivasi antara lain:

a. Mendorong manusia untuk berbuat. Jadi, sebagai penggerak atau motor yang melepaskan energi. Motivasi dalam hal ini merupakan motor penggerak dari setiap kegiatan yang akan dilakukan.

b. menentukan arah perbuatan, yaitu kearah tujuan yang hendak dicapai. Dengan demikian motivasi ini dapat memberikan arah dan kegiatan yang dilakukan sesuai dengan tujuannya.

c. menyeleksi perbuatan, yaitu menentukan perbuatan apa yang harus dikerjakan yang serasi guna mencapai tujuan.

Di samping itu ada juga fungsi-fungsi lain. Motivasi dapat berfungsi sebagai pendorong usaha dan pencapaian prestasi. Seseorang melakukan suatu usaha karena adanya motivasi yang baik akan menunjukkan hasil yang baik pula. ${ }^{25}$

Dengan demikian motivasi merupakan fungsi dari medan di saat sedang terjadi sehingga tingkahlaku perbuatan manusia merupakan fungsi untuk menyelesaikan diri pada saat peristiwa atau proses terjadinya.

Melihat pentingnya fungsi motifasi dalam prilaku organisasi, maka Thorndike ahli ilmu jiwa aliran behaviorisme di amerika serikat, menciptakan suatu hukum efek (Law Of Effect) menurut hukum ini hubungan yang dibentuk oleh organisme antara situasi ransangan dengan response (jawaban) menjadi kuat bilamana response tersebut diikuti oleh suatu pemenuhan terhadap kepuasan atau diikuti oleh pengurangan terhadap suatu kebutuhan (Need Reductio) $)^{26}$

\section{Prestasi Belajar Siswa}

Kemampuan intelektual siswa sangat menentukan keberhasilan siswa dalam memperoleh prestasi. Untuk mengetahui berhasil tidaknya seseorang dalam belajar maka perlu dilakukan suatu evaluasi, tujuannya untuk mengetahui prestasi yang diperoleh siswa setelah proses belajar mengajar berlangsung.

Menurut Nasrun Harahap dkk, prestasi didefinisikan sebagai suatu penilaian pendidikan tentang perkembangan dan kemajuan murid yang berkenaan dengan penguasaan bahan pelajaran yang disajikan kepada mereka serta nilai-nilai yang terdapat dalam kurikulum. ${ }^{27}$ Adapun prestasi menurut Kamus Besar Bahasa Indonesia adalah hasil yang telah dicapai dari usaha yang telah dilakukan dan dikerjakan. ${ }^{28}$

Prestasi belajar merupakan hal yang tidak dapat dipisahkan dari kegiatan belajar karena kegiatan belajar merupakan proses, sedangkan prestasi merupakan hasil dari proses belajar. Memahami pengertian prestasi belajar secara garis besar harus bertitik tolak kepada

\footnotetext{
${ }^{25}$ Sardiman AM, Interaksi dan Motivasi Belajar Mengajar (Pedoman Bagi Guru dan Calon Guru), (PT. Raja Gravindo Persada, Jakarta, 1994), h 84-85.

${ }^{26}$ H.M. Arifin, Psikologi Da'wah Suatu Pengantar Studi, h. 72.

${ }^{27}$ Saiful Bakri Djamarah, Prestasi Belajar dan Kompetensi Guru, (Surabaya: Usaha Nasional, 1994), h. 21 .

${ }^{28}$ Tim Penyusun, Kamus Besar Bahasa Indonesia, (Cet. I; Jakarta: Balai Pustaka, 1998), h. 787.
} 


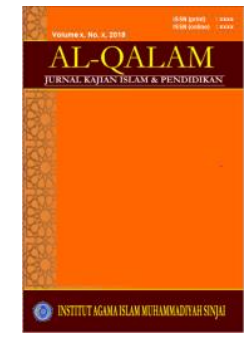

AL-QALAM

Jurnal Kajian Islam \& Pendidikan

Volume 7, No. 1, 2015

ISSN (print) : 1858-4152

ISSN (online) : 2715-5684

Homepage : http://journal.al-qalam.iaims.ac.id

pengertian belajar itu sendiri. Untuk itu para ahli mengemukakan pendapatnya yang berbedabeda sesuai dengan pandangan mereka. Namun dari pendapat yang berbeda itu dapat kita temukan satu titik persamaan sehubungan dengan prestasi belajar.

Pengertian prestasi belajar yang terdapat Dalam Kamus Besar Bahasa Indonesia adalah penguasaan pengetahuan atau keterampilan yang dikembangkan oleh mata pelajaran, lazimnya ditunjukkan denga nilai tes atau angka nilai yang diberikan oleh guru. ${ }^{29}$

Jadi, prestasi belajar adalah hasil yang dicapai oleh siswa selam berlangsungnya proses belajar mengajar dalam jangka waktu tertentu, umumnya prestasi belajar dalam sekolah berbentuk pemberian nilai (angka) dari guru kepada siswa sebagai indikasi sejauhmana siswa telah menguasai materi pelajaran yang disampaikannya. Biasanya prestasi belajar ini dinyatakan dengan angka, huruf atau kalimat dan terdapat dalam periode tertentu . Prestasi siswa dapat diketahui setelah diadakan evaluasi. Hasil dari evaluasi dapat memperlihatkan tentang tinggi atau rendahnya prestasi belajar siswa.

\section{Faktor-Faktor Yang Mempengaruhi Prestasi Belajar}

Faktor yang mempengaruhi prestasi belajar untuk mencapai prestasi belajar siswa sebagaimana yang diharapkan maka perlu diperhatikan beberapa faktor yang mempengaruhi prestasi belajar yaitu faktor internal (faktor dari dalam diri siswa) adalah yang bersifat biologis, dan faktor eksternal (faktor dari luar diri siswa) adalah faktor keluarga, sekolah, masyarakat dan sebagainya.

a. Faktor internal

Faktor internal adalah faktor yang timbul dari dalam diri individu itu sendiri, adapun termasuk faktor internal yaitu:

1. Kecerdasan/intelegensi

Kecerdasan adalah kemampuan belajar disertai kecakapan untuk menyesuaikan diri dengan keadaan yang dihadapinya. Kemampuan ini sangat ditentukan oleh tinggi rendahnya intelegensi yang normal selalu menunjukkan kecakapan sesuai dengan tingkat perkembangan sebaya. Slameto mengatakan bahwa tingkat intelegensi yang lebih tinggi akan lebih berhasil daripada yang mempunyai tingkat intelegensi yang rendah. ${ }^{30}$

Muhibbin berpandapat bahwa intelegensi adalah semakin tinggi kemampuan intelegensi seseorang siswa mak semakin besar peluangnya untuk meraih sukses. Sebaliknya semakin rendah kemampuan intelegensi seseorang siswa maka semakin kecil peluangnya untuk meraih sukses. ${ }^{31}$

Dari pendapat di atas jelaslah bahwa intelegensi yang baik atau kecerdasan yang tinggi merupakan faktor yang sangat penting bagi seorang anak dalam usaha belajar.

2. Minat

\footnotetext{
${ }^{29}$ Ibid., h. 700.

${ }^{30}$ Slameto, Belajar dan Faktor-Faktor Yang Mempengaruhinya, (Jakarta: Rineka Cipta, 1995), h. 56.

${ }^{31}$ Muhibbin Syah, Psikologi Pendidikan, (Bandung: PT Rosdakarya, 1995), h. 134.
} 


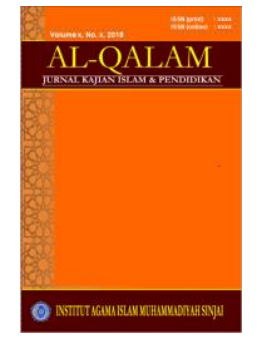

AL-QALAM

Jurnal Kajian Islam \& Pendidlikan

Volume 7, No. 1, 2015

ISSN (print) : 1858-4152

ISSN (online) : 2715-5684

Homepage : http://journal.al-qalam.iaims.ac.id

Minat adalah kecenderungan pada individu yang menyangkut perasaan suka atau tidak suka terhadap hal tertentu. Slamete mengemukakan bahwa minat adalah kecenderungan yang tetap untuk memperhatikan dan mengenang beberapa kegiatan, kegiatan yang diminati seseorang, diperhatikan terus menerus yang disertai dengan rasa senang. ${ }^{32}$

Berdasarkan pandapat di atas, jelaslah bahwa minat besar pengaruhnya terhadap belajar. Bahkan pelajaran yang menarik minat siswa lebih mudah dipelajari dan disimpan karena minat menambah kegiatan belajar.

3. Motivasi

Motivasi adalah segala sesuatu yang mendorong segala seseorang untuk bertindak melakukan sesuatu. ${ }^{33}$ Motivasi berprestasi merupakan daya penggerak psikis dalam diri seseorang yang menimbulkan semangat belajar, menjamin kelangsungan kegiatan belajar dan memberikan arah pada kegiatan belajar demi tercapainya tujuan. Motivasi dapat dibedakan menjadi dua macam, yaitu:

a) Motivasi intrinsik

Motivasi intrinsik adalah hal dan keadaan yang berasal dari dalam siswa sendiri yang dapat mendorongnya melakukan tindakan belajar, misalnya perasaan butuh siswa terhadap materi yang dipelajari untuk masa depannya.

b) Motivasi ekstrinsik

Motivasi ekstrinsik adalah hal dan keadaan yang datang dari luar individu siswa yang juga mendorongnya untuk melakukan kegiatan belajar, misalnya pujian/hadiah, tata tertib sekolah, suri tauladan orang tua dan guru. ${ }^{34}$

b. Faktor eksternal

Faktor eksternal adalah faktor-faktor yang dapat mempengaruhi prestasi belajar yang sifatnya di luar diri siswa, yaitu beberapa pengalaman-pengalaman, keadaan keluarga, lingkungan sekitarnya dan sebagainya.Pengaruh lingkungan ini pada umumnya bersifat positif dan tidak memberikan paksaan kepada individu. Menurut Slameto faktor eksternal yang dapat mempengaruhi kegiatan belajar adalah keadaan keluarga, keadaan sekolah, dan keadaan lingkungan masyarakat. ${ }^{35}$

1. Keadaan Keluarga

Adanya rasa aman dalam keluarga sangat penting dalam keberhasilan seseorang. Rasa aman itu membuat seseorang akan terdorong untuk belajar secara aktif karena rasa aman merupakan salah satu kekuatan pendorong dari luar yang menambah motivasi untuk belajar. Hendaknya orang tua menyadari bahwa pendidikan dimulai dari keluarga, sedangkan sekolah merupakan pendidikan lanjutan.

2. Keadaan Sekolah

\footnotetext{
${ }^{32}$ Slameto, Op. Cit., h. 57.

${ }^{33}$ M. Ngalim Purwanto, Op. Cit., h. 69.

${ }^{34}$ Muhibbin Syah, Op. Cit., h. 137.

${ }^{35}$ Slameto, Op. Cit., h. 60.
} 




AL-QALAM

Jurnal Kajian Islam \& Pendidikan

Volume 7, No. 1, 2015

ISSN (print) : 1858-4152

ISSN (online) : 2715-5684

Homepage : http://journal.al-qalam.iaims.ac.id

Sekolah merupakan lembaga pendidikan formal pertama yang sangat penting dalam menentukan keberhasilan belajar siswa, karena itu lingkungan sekolah yang baik dapat mendorong untuk belajar yang lebih giat. Keadaan sekolah ini meliputi cara penyajian pelajaran, hubungan guru dengan siswa, alat-alat pelajaran dan kurikulum. Hubungan antar guru dengan siswa kurang baik akan mempengaruhi hasil-hasil belajarnya.

3. Keadaan Lingkungan Masyarakat

Disamping orang tua, lingkungan juga merupakan salah satu faktor yang tidak sedikit pengaruhnya terhadap hasil belajar siswa dalam proses pelaksanaan pendidikan. Karena lingkungan alam sekitar sangat besar pengaruhnya terhadap perkembangan pribadi anak, sebab dalam kehidupan sehari-hari akan lebih banyak bergaul dengan lingkungan dimana anak itu berada.

Dengan demikian dapat dikatakan lingkungan membentuk kepribadian anak, karena dalam kehidupan sehari-hari seorang anak akan selalu menyesuaikan dirinya dengan kebiasaan-kebiasaan lingkungannya. Oleh karena itu, apabila seorang siswa bertempat tinggal di suatu lingkungan temannya yang rajin belajar maka kemungkinan besar hal tersebut akan membawa pengaruh pada dirinya, sehingga ia akan turut belajar sebagaimana temannya.

\section{PENUTUP}

Berdasarkan uraian pembahasan di atas, dapat disimpulkan beberapa hal, yaitu:

1. Salah satu inisiatif guru agama yang dapat menumbuhkan kreativitas belajar siswa pada tujuan utama pendidikan yaitu dengan menggunakan metode probing question (pertanyaan menggali) dengan menggunakan metode probing question menjadikan siswa lebih kreatif dalam berfikir dan siswa mendapatkan informasi dari jawaban yang lengkap dan jelas.

2. Prestasi belajar merupakan hal yang tidak dapat dipisahkan dari kegiatan belajar karena kegiatan belajar merupakan proses, sedangkan prestasi merupakan hasil dari proses belajar. Motivasi dapat berfungsi sebagai pendorong usaha dan pencapaian prestasi. Seseorang melakukan suatu usaha karena adanya motivasi yang baik akan menunjukkan hasil yang baik pula. Dengan demikian dituntut peran orang tua dan guru untuk selalu memotivasi peserta didik diberbagai rana kehidupan maupun lingkungan belajarnya. 


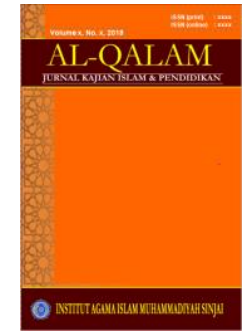

AL-QALAM

Jurnal Kajian Islam \& Pendidikan

Volume 7, No. 1, 2015

ISSN (print) : 1858-4152

ISSN (online) : 2715-5684

Homepage : http://journal.al-qalam.iaims.ac.id

\section{DAFTAR PUSTAKA}

Ahmadi Abu. Psikologi Belajar, Jakarta: Rineka Cipta, 1991

Al. et. Muhaimin. Paradigma Pendidikan Islam: Upaya Mengektifkan Pendidikan Agama Islam Di Sekolah, Bandung: PT Remaja Rosdakarya, 2004

AM. Sardiman, Interaksi dan Motivasi Belajar Mengajar (Pedoman Bagi Guru dan Calon Guru), PT. Raja Gravindo Persada, Jakarta, 1994

Candra Julius, Kreativitas: Bagaimana Menanam, Membangun dan Mengembangkannya, Yogyakarta: Kanisius, 1994

Daradjat Zakiah, Kepribadian Guru. Jakarta : Bulan Bintang, 1980

Djamarah Bakri Saiful, Prestasi Belajar dan Kompetensi Guru, Surabaya: Usaha Nasional, 1994

Hamalik Oemar, Psikologi Belajar Mengajar, Bandung: PT. Sinar Baru al Gesindo, 2000

Hasan Shadily dan John M. Echols, Kamus Inggris Indonesia, Cet. XXIV, Jakarta : PT. Gramedia Pustaka Utama, 2000

Hasan Chalijah H., Dimensi-dimensi Psikologi Pendidikan, Surabaya :Al-Ikhlas, 1994

Makmun Syamsuddin Abin, Psikologi Pendidikan, Cet V, Bandung: PT. Remaja Rosda Karya, 2002

Mayulis R.A., Ilmu Pendidikan Islam, Jakarta : Kalam Mulia, 1998

Munandar Utami, Pengembangan Kreativitas Anak Bakat, Jakarta: PT. Rineka Cipta, 1999

Muhibbin, Syah. Psikologi Pendidikan, Bandung: PT Rosdakarya, 1995

Noeng Muhadjir. Mencari Paradigma Untuk Membuat Antisipasi. Makalah Disampaikan Pada Kulaih Pascasarjana IAIN Yogyakarta Yogyakarta: IAIN Yogyakarta

Pasiak Taufik, Revolusi IQ/EQ/SQ, Bandung: Mizan, 2003

Rahardja. Dawam M, Islam Indonesia Menatap Masa Depan. Jakarta:P3M, 1989

Ramayulis, Ilmu Pendidikan Islam. Jakarta: Kalam Mulia, 1994

Roestiyah NK. Masalah Pengajaran Sebagai Suatu Sistem. Jakarta : PT. Bina Aksara, 1982 


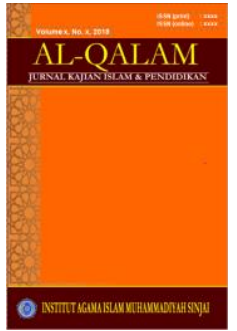

AL-QALAM

Jurnal Kajian Islam \& Pendidikan

Volume 7, No. 1, 2015

ISSN (print) : 1858-4152

ISSN (online) : 2715-5684

Homepage : http://journal.al-qalam.iaims.ac.id

Shaleh Rachman Abdul , Pendidikan Agama dan Pembangunan watak Bangsa. Jakarta: Grafindo Persada, 2005

Syafi'I Hadcami Moh., Tauhidul Addilah. Surabaya: Menara Kusud, 1986

Suryabrata Sumadi, Psikologi Pendidikan, Jakarta : Rajawali Pers, 1990

Slameto, Belajar dan Faktor-Faktor Yang Mempengaruhinya, Jakarta: Rineka Cipta, 1995

Tim Penyusun, Kamus Besar Bahasa Indonesia, (Cet. I; Jakarta: Balai Pustaka, 1998), h. 787.

Undang-Undang RI No. 20 Tahun 2003 Tentang Sistem Pendidikan Nasional.

Purwanto. Ngalim M, Psikologi Pendidikan., Bandung :PT. Remaja Rosda Karya, 1996 